\title{
China's strategy toward Central Asia: interests, principles and policy tools
}

\author{
Feng Yujun \\ Fudan University, 220 Handan Road, Yangpu District, 200433, Shanghai
}

For citation: Feng Yujin. China's strategy toward Central Asia: interests, principles and policy tools. Vestnik of Saint Petersburg University. International Relations, 2019, vol. 12, issue 1, pp. 23-39. https://doi.org/10.21638/11701/spbu06.2019.102

In nearly 30 years since the collapse of the Soviet Union, China and the five Central Asian countries have formed a strategic partnership of equal trust and mutual benefit. China's interests in Central Asia focus on maintaining security in border areas, combating terrorism and extremism, gaining access to stable energy supplies, and expanding overseas markets and investment returns. In the course of its communication with the Central Asian countries, China claims its deep commitment to such principles as peaceful coexistence of all nations, non-use of pressure, military force or threats, mutual respect, refraining from establishing a sphere of influence and promotion of regional peace and development. The main policy tools for China to pursue its grand strategy in Central Asia include properly handling border issues, eliminating potential conflicts, developing good-neighborly and friendly relations with Central Asian countries. In order to achieve mutual benefit and win-win situation, China will continuously upgrade the level of strategic partnership, actively develop economic cooperation and energy cooperation with Central Asian countries. In addition, China will develop comprehensive cooperation with Central Asian countries through the Shanghai Cooperation Organization, balancing the interrelationships with Russia, the United States and other international actors (including some intergovernmental organizations) in Central Asia.

Keywords: China, Central Asia, national interests, principles of diplomacy, policy tools.

After the collapse of the Soviet Union, the five Central Asian countries, namely Kazakhstan, Kyrgyzstan, Tajikistan, Uzbekistan and Turkmenistan, became independent international law subjects, and Central Asia became a new geopolitical region in the international landscape. After the development of nearly 30 years, China and Central Asian countries have established a strategic partnership, and the multi-dimensional cooperation has been carried out in political, economic, cultural, security fields and so on. This paper will start with an analysis of China's interests in Central Asia, reviewing the main course of the development of relations between China and Central Asian countries in the past 30 years, analyzing China's policy measures and policy effects on Central Asia, anticipating China's future direction in Central Asia.

\section{China's Strategic Interests in Central Asia}

China's basic interests in Central Asia can be summarized as security interests, economic interests, energy interests and geopolitical interests. Defining interests is the basis for determining China's strategy toward Central Asia.

(c) Санкт-Петербургский государственный университет, 2019 
First of all, the border issue with the Central Asian countries should be resolved and border security should be maintained. China and three Central Asian countries-Kazakhstan, Kyrgyzstan, Tajikistan share a borderline of more than 3,000 kilometers. On the occasion of the Sino-Soviet confrontation in the 1960s and 1970s, a series of border conflicts took place between China and the Soviet Union. China faced enormous security pressures in the north and northwest, and border disputes have become a major obstacle to Sino-Soviet relations. In the early 1980s, the tension between China and the Soviet Union began to ease, and the two countries embarked on negotiations on the border issue including the western border of China. However, when the Soviet Union collapsed at the end of 1991, no concrete results were achieved. Securing border security has become one of the important tasks of China's strategy toward Central Asia.

During the late 1990s, extremist forces in Central Asia and the "East Turkistan" terrorist forces echoed with the support of international terrorist organizations and a series of terrorist incidents have been created in southern Central Asia and in Xinjiang, China, causing a large number of deaths and injuries. After the "September 11" incident, new changes have taken place in the situation and terrorist forces transferred from Afghanistan to Central Asia. The task of fighting against the "Three Evil Forces" is more urgent. Cross-border cooperation should be carried out and all regions and countries need to work together. Considering that the northwestern part of China is a Xinjiang Uygur Autonomous Region inhabited by ethnic minorities in China, there are "Three Evil Forces" of separatism, terrorism and extremism, as well as drug production and trafficking, transnational crimes, which are the most significant non-traditional security challenge for China's national security. Therefore, it is common need for China and Central Asian countries to cooperate and confront the threat posed by the "Three Evil Forces" and other nontraditional security factors to national security and regional stability.

Secondly, economic cooperation with the Central Asian countries on the basis of equality and mutual benefit should be developed, promoting them to integrate into the world economic system, exploiting their market. During the Soviet times, the links between Central Asia and the world economic system were very weak. After the collapse of the Soviet Union, Central Asian countries entered into the world economic system as independent economies, thus they became China's new economic partners Central Asia consists of China's foreign economic cooperation. China has extensive economic benefits in Central Asia, including trade, economic infrastructure, and mineral exploitation and so on. On the one hand, Xinjiang and Central Asia are geographically adjacent and maintained long-time economic ties. Until the late Republic of China, Russian Central Asia was still Xinjiang's most important economic partner. After the 1950s, two regions' economic ties were broken up. In the context of globalization, China hopes to promote Xinjiang's economic development and opening up by expanding economic cooperation with Central Asian countries. On the other hand, after the "Belt and Road" initiative was put forward, Central Asia's position in China's foreign economic cooperation has further increased. Central Asia is not only the region with the most achievements in the construction of the "Belt and Road", but also the key area for the construction of the "Belt and Road" in the future. In the longer term, China hopes that regional economic integration in Central Asia will make more progress, because it will provide more solid regional support for globalization and provide a broader prospect for economic cooperation between China and Central Asian countries. 
The third is to strengthen mutually beneficial energy cooperation with Central Asian countries, obtain the energy resources necessary for China's economic development while providing investment, technology and a huge and stable energy export market for Central Asian countries. According to BP's "World Energy Statistics Yearbook", oil reserves in Central Asia are about 4 billion tons in 2016, accounting for $1.83 \%$ of the world's total reserves. Among them, Kazakhstan obtains the greatest growing potential of oil in Central Asia, with oil reserves of 3.9 billion tons, accounting for $1.63 \%$ of the world's oil reserves, ranking $12^{\text {th }}$ in the world. Natural gas reserves in Turkmenistan are 1.75 billion cubic meters, accounting for $9.4 \%$ of the world's total, ranking third in the world, storage/ production ratio exceeding a century [1]. Due to its rich energy savings and unique geostrategic position, Central Asia's position in the world geopolitical landscape of energy rises significantly. With the continuous economic development, China's dependence on foreign energy is increasing. To ensure the realization of energy benefits, China needs to ensure the opening of Central Asian energy resources to China. It is undesirable that any foreign countries control and monopoly on Central Asian energy. China and Central Asia's energy cooperation are strategically complementary and there are broad strategic prospects in the fields of oil trade, exploration and development of oil and gas resources and oil and gas product processing technology. At present, China and Central Asian countries have formed extensive cooperation in trading, exploration and development of oil and gas fields, oil and gas engineering technical services, oil and gas refining project contracting and so on. It should be emphasized that the energy cooperation between China and Central Asian countries is based on mutually beneficial and win-win principle. China has obtained a large and stable supply of energy from Central Asian countries, and Central Asian countries have obtained a large amount of investment, advanced technology and stable and huge oil and gas export market from China. Energy cooperation with China has important strategic significance for the economic development of Kazakhstan, Turkmenistan and other countries.

The fourth is to support the sovereignty, independence and territorial integrity of Central Asian countries, supporting them to choose an independent development path, ensuring that they become China's good-neighborly and friendly zone. It is the disintegration of the Soviet Union and the subsequent development of relations between China, Russia and Central Asian countries that greatly improved China's strategic security environment. This is also an important prerequisite for China to focus its strategic efforts on economic development and national modernization. Based on the strategic interests, China's geopolitical interests in Central Asia include maintaining the strategic stability and security of the region, preventing the emergence of any strategic threat or politicomilitary group in the region for China and opposing military competition among outside military forces in Central Asia.

\section{The Main Principles of China's Strategy toward Central Asia}

The "Five Principles of Peaceful Coexistence", the "Harmonious World" and the "Shared Future" are the core concepts of China's foreign strategy in the past 40 years of reform and opening up. Starting from these concepts, China's Central Asia strategy should follow the following main principles: 
Firstly, relations between Central Asian countries should be handled by peaceful means without force or threats of force, and are committed to consolidating mutual trust with Central Asian countries through all-round cooperation. China pursues the foreign policy of "being a good neighbor and partner" and "build an amicable, tranquil and prosperous neighborhood". When China and Central Asian countries develop cooperation, they highlight the word "goodness". It reflects the traditional concept of Chinese diplomacy and the essence of pursuing world peace. Peace is one of the basic properties of China's diplomacy in Central Asia. The peaceful nature of China's diplomacy in Central Asia does not simply refer to its external form, but more importantly its spiritual connotation. Cooperation is a positive and constructive gesture. It indicates that China has positioned itself as a builder and partner to develop a relationship with Central Asian countries in a constructive manner. The second is to adhere to the principle that countries, no matter big or small, should respect each other. Central Asia is a relatively weak surrounding area for China, but in the course of mutual exchanges in the past 30 years, China and Central Asian countries fully considered the relationship of "Serve a small country as a great one". China always considers Central Asian countries' feelings and needs when we get along. In bilateral relations with Central Asian countries, China understands the weak position of Central Asian countries. In this way, China can understand the sensitivity of Central Asian countries to self-esteem and pay special attention to political, economic and security interests in bilateral relations. This will enable China to consciously pay attention to maintaining political equality and play a more constructive role in security and economy. China adheres to the "win-win" approach, especially in economic cooperation. At the beginning of independence of Central Asian countries, everything needed to be rebuilt, and foreign help is badly needed to help within its capacity to Central Asian countries. When they face difficulties or need assistance, China can give a helping hand each time without any political conditions.

China fully understands and respects the "multiple balanced" diplomatic theory and practice of Central Asian countries. After independence, the Central Asian countries chose the balanced policy and multilateral diplomacy, although the diplomatic focus and inclination of the countries were different. Turkmenistan chose the principle of "active neutrality". This is not accidental, which has both the influence of historical traditions and the requirements of realistic conditions. China believes that Central Asia should become an open region and support the "diversified diplomacy" of Central Asian countries. China needs to take into consideration the factor of the pluralistic diplomacy of Central Asian countries. Balanced and pluralistic diplomacy will be the most likely choice for Central Asian countries unless there is a major geopolitical change. Balanced and diversified diplomacy has important implications for China. It means that developing relations with China is an important, but not the only option for Central Asian countries; Central Asian countries regard China as an important partner, but will not "turn toward" China; Central Asian countries are not only expecting, but also limiting China's development in Central Asia. They may use China to balance other big powers, and at the same time use them to counterbalance China. For China, it understands the rationality of diversified diplomacy to Central Asian countries and knows that it does not aim at China. It is not necessary to be too suspicious and sensitive, leading to a shackle of deeper development and relations with Central Asia. At the same time, it is necessary to have a clear understanding of the restrictive role of diversified diplomacy in China. Diversified diplomacy is both a challenge 
and an opportunity for China. China will always be one of the "directions" of Central Asian countries. Moreover, China will always be one of the most important "directions" of Central Asian countries due to China's geographical and geopolitical advantages, which may give it more opportunities than other big powers.

The third is to adhere to the cautious "non-confrontation" principle, and strive to resolve differences with Central Asian countries through equal consultation and deal with relations with other big powers in Central Asia. There are many variables affecting this region due to the political, economic, and social and security vulnerabilities of Central Asia. This region is affected by internal and external changes to a greater extent, and its development has obvious variability, uncertainty and unpredictability. At the same time, Central Asia is one of the important regions for international geopolitical competition. Many world and regional powers have their own interests and influences in this region. Therefore, China's policy toward Central Asia is very cautious. Starting from the idea of peaceful development and a harmonious world, China follows the principle of nonconfrontation, not using the Cold War mentality, not engaging in "zero-sum games", not disapproving of seeing Central Asia as a "big chess game" and opposing the recurrence of the "big game". While non-confrontation does not mean that China gives up its position and interests, China firmly maintains its principles and defends its legitimate rights and interests in Central Asia.

The fourth is not to seek to establish a sphere of influence. China actively participates in regional cooperation in Central Asia, but does not seek to establish its own sphere of influence. From objective conditions, this is not impossible. China actively promotes the development of the Shanghai Cooperation Organization (SCO), but does not intend to form a military and political group in Central Asia. China does not want SCO to become a NATO-like organization. China is striving to develop relations with the region, but China's intention is to carry out regional cooperation, rather than compete for dominance with other countries, and does not intend to challenge any big power [2].

In this regard, China fully understands the traditional influence and real interests of Russia in Central Asia. Central Asia was subordinated to the Russian Empire and the Soviet Union for a century and a half. The long-term rule of Russia and the former Soviet Union in Central Asia left a huge historical legacy. After the collapse of the Soviet Union, although Central Asian countries began a new national renaissance, the influence of Russia still profoundly existed. The traces of "Russification" of Central Asian countries are very obvious in language, culture, education, social life, political management, and even the way of thinking. In reality, Russia and Central Asian countries have close links in political, economic, security, diplomatic, and humanistic fields. Russia's influence on Central Asia is extensive and deep. Russia has important security and economic interests in Central Asia. China not only fully understands and pays high attention to this, but also conducts in-depth cooperation with Russia and Central Asian countries through the important platform of SCO in practice, safeguarding the security and stability of Central Asia and promoting the development of Central Asia.

The fifth is to build a "harmonious region" in Central Asia. Establishing a harmonious region is a universal policy of China's diplomacy, not only in Central Asia, but also in other regions. However, in terms of building a harmonious region, Central Asia has a certain special significance for Chinese diplomacy. It is for Central Asia that China first proposed the concept of a harmonious region. In June 2006, in his speech at the SCO summit in 
Shanghai, Chinese President Hu Jintao proposed to build the region into a "harmonious region of lasting peace and common prosperity" [3]. This may be the first time that China has applied the policy of a harmonious region to a specific region. It is in Central Asia that China first put forward the "Shanghai Spirit" of "mutual trust, mutual benefit, equality, consultation, respect for diverse civilizations, and seeking common development". It is in Central Asia that China systematically proposed a new security concept and a cooperative view of common security, non-alignment, non-confrontation, and non-targeting to third countries. It is still in Central Asia that China first attempts to establish a new regional cooperation organization. It may not be accidental and it reflects the fact that Central Asia is a region suitable for China to introduce a new concept of diplomacy and is also suitable for China to try to apply its new idea to practice. In this regard, Central Asia can play a leading role in the process of establishing a harmonious region.

\section{The Policy Tools of China's Strategy toward Central Asia}

On the basis of obvious strategic interests and strategic principles, China has deepened all-round cooperation with Central Asian countries through a series of policy tools in the past 30 years and achieved good results.

The first is to compromise the border issues left over by history, eliminate potential conflicts, and continuously strengthen cooperation in traditional and non-traditional security. In May 2002, Kazakhstan and China signed a demarcation protocol, drawing a satisfactory conclusion for the solution of the Sino-Kazakh border issue. Among the former Soviet Union countries, Kazakhstan took the lead in completely resolving the border issues left over by history with China. In the same month, China and Tajikistan signed the "Border Supplementary Agreement" and finally reached an agreement in the disputed area. In June 2002, the President of Kyrgyzstan signed an order to approve the relevant agreement on the Sino-Kyrgyz border, marking that the Sino-Kyrgyzstan border issues are fully resolved. The long land boundary line has become a bond that closely links China's friendship with the three Central Asian neighbors and lays a solid foundation for the development of good-neighborly friendship and cooperation between China and Central Asian countries.

While compromising the settlement of the border issue, China and Central Asian countries have also made progress in strengthening military trust and border security. In February 1995, China has made a promise that would not use nuclear weapons against Kazakhstan and other Central Asian countries. In April 1996, China, Kazakhstan, Kyrgyzstan, Tajikistan and Russia signed "Agreement on Strengthening Military Trust in Border Areas". In April 1997, the above-mentioned countries signed the "Agreement on Mutual Reduction of Armed Forces in Border Areas". Mutual disarmament in the border areas and strengthening military mutual trust in the border areas have greatly improved the security relationship between China and Central Asian countries, making the oncedefunct borders a boundary for cooperation.

Secondly, good-neighborly and friendly relations with Central Asian countries should be developed and the level of strategic partnership relations should be improved. In June 2002, China and Kyrgyzstan signed the "Good-Neighborly Friendship and Cooperation Treaty". In December, China and Kazakhstan signed the "Good-Neighborly Friendship and Cooperation Treaty", Cooperation Agreement on Combating Terror- 
ism, Separatism and Extremism" and so on. In May 2005, China and Uzbekistan signed a "Treaty of Friendship and Cooperation Partners". In January 2007, China and Tajikistan signed the "Good-Neighborly Friendship and Cooperation Treaty". These four important treaties have set down the sincere wish of China, Central Asian countries and the people of Central Asian countries for friendship from generation to generation in the form of law. It will become a programmatic document for the development of friendly relations between China and Central Asian countries in the new century. The signing of the treaty marks the promotion of bilateral relations to a higher and more quality level.

In 2005, China-Kazakhstan relations rose from a friendly and cooperative partnership to a strategic partner. In 2011, it was upgraded to a comprehensive strategic partnership. In 2013, it entered into a "new phase" of comprehensive strategic partnership. In 2012, the two countries established the "Prime Minister Regular Meeting Mechanism", forming an official cooperation platform led by "Prime Minister's Annual Meeting + China-Kazakhstan Cooperation Committee +10 Sub-Committees". The sub-committees are economic and trade, transportation, railway, port and customs, science and technology, finance, energy, geology and mineral resources, humanities and security.

China and Uzbekistan formally established a friendly cooperative partnership in 2005 , and in 2012, they upgraded to strategic partners. In June 2016, it was upgraded to a comprehensive strategic partnership again. The two countries established the Deputy Prime Minister's Intergovernmental Cooperation Committee in 2011. There are 7 subcommittees, including economy, trade, transportation, science and technology, energy, humanities, security and agriculture, forming a cooperation platform led by the "intergovernmental cooperation committee + sub-committee", and maintaining frequent contacts and cooperation in various fields of concern to the two countries.

China and Tajikistan established a strategic partnership and upgraded to a comprehensive strategic partner on August 31, 2017. In 2001, the two countries established the mechanism of intergovernmental economic and trade cooperation committee, which was led by the commercial departments of the two countries. The main tasks were to supervise the implementation of the agreement, propose cooperation proposals, and resolve related issues. The date of the meeting of the committee is not fixed and will be negotiated as needed. The $9^{\text {th }}$ meeting was held in Beijing in August 2017. In 2009, the two countries established the "China Xinjiang-Tajikistan Economic and Trade Cooperation Sub-Committee" under the framework of the Economic and Trade Cooperation Committee, and held a meeting every two years.

China and Kyrgyzstan established a strategic partnership in 2013. As early as 1994, the two countries established a ministerial-level intergovernmental economic and trade cooperation committee mechanism, led by the business departments of the two countries. The main tasks are to supervise the implementation of the agreement, propose cooperation proposals, and resolve related issues. However, the date of the committee meeting is not fixed and will be negotiated as needed.

China and Turkmenistan established a strategic partnership in 2013. The two countries established a ministerial intergovernmental economic and trade cooperation committee mechanism in 1998, led by the heads of the business departments of the two countries. With the deepening of cooperation in oil and gas and other fields, the two countries established the Deputy Prime Minister-level Intergovernmental Cooperation Committee 
in 2010. The meeting is held every two years and consists of four sub-committees: economy, trade, humanities, security and energy.

The third is to actively develop mutually beneficial and win-win economic cooperation with Central Asian countries. In the past 30 years, the trade volume between China and Central Asian countries has increased nearly 100 times. In recent years, the Central Asian countries have been actively carrying out the docking between their own development strategies and China's "Belt and Road" initiative to seek common development. China is Kazakhstan's second largest trading partner and sixth largest source of investment. During 2012-2016 China-Kazakhstan total trade rose from $\$ 13.1$ billion to $\$ 28.5$ billion. China's exports to Kazakhstan consist mainly of light equipment products such as machinery, electronics, textiles and clothing, and imports from Kazakhstan are mainly oil, natural gas, minerals (copper, uranium, etc.), grain and other agricultural products. According to official statistics of Kazakhstan, by the end of 2016, China's direct investment in Kazakhstan is US \$3.51 billion (accounting for $2.7 \%$ of Kazakhstan's total foreign direct investment stock), but according to the statistics of China, it was $\$ 5.432$ billion. There are 2637 Chinese enterprises registered in Kazakhstan, mainly involving mineral exploration and development, petrochemicals, gas stations, agricultural products processing, catering and accommodation [4]. As of May 2017, the total number of key cooperation projects in the "Belt and Road" framework of China and Kazakhstan totals \$27 billion. 34 projects have been completed, such as Aktoga's dressing plant that produces 2500 tons of copper per year, Pavlodar's factory that produces 2500 tons electrolytic aluminum per year. 43 projects are now being implemented, such as deep processing of petroleum of Atyrau Refinery. In addition, Sino-Kazakhstan logistics base (Lianyungang), Lianyungang SCO international logistics park and "Horgos-Dongdamen" special economic zone officially opened. Horgos is already in operation. Sino-Kazakhstan High-tech Industrial Park and the Agricultural Products Processing Logistics Park are under construction.

China is Uzbekistan's largest trading partner and largest source of investment. From 2012 to 2016, China-Uzbekistan's total trade rose to $\$ 4.551$ billion from $\$ 2.875$ billion. As of the end of 2016, China's direct investment stock in Uzbekistan was 1.058 billion, and the cumulative amount of various types of loans was about $\$ 5.5$ billion. China has registered 704 enterprises and 74 representative offices in Uzbekistan and a total of more than 70 cooperation projects have been implemented, mainly concentrating in the fields of energy, mineral resources development, electronics and light industry [5]. China-Uzbekistan cooperation projects mainly include: the construction of Pengsheng Industrial Park in the Sil River State; solar water heater produced by Hangzhou Zhongwu Electronic Instrument Co., Ltd. and Gizak State Grid Corporation Wuxi Suntech Solar Co., Ltd; solar panels produced by Wuxi Suntech Solar Company in Navoi; ZTE Corporation produces smartphones in Pengsheng Industrial Park; ZTE's smartphones produced in Pengsheng Industrial Park, refrigerators and TV sets produced by Midea and Changhong in Pengsheng Park and engineering contracting project for the Camchik Tunnel of the Anglian-Pap Railway.

China is the largest trading partner, the largest source of investment and largest creditor of Tajikistan. From 2012 to 2016, the trade volume of Sino-Tajikistan Trade rose from $\$ 1.556$ billion to $\$ 2.517$ billion. As of the end of 2016, China's non-financial direct investment in Tajikistan is $\$ 1,167$ million (\$272 million in 2016) [6]. There are two main aspects of the Sino-Tajikistan Cooperation project: the engineering contracting projects 
mainly include the Wahdat-Yawan Bridge and Tunnel Project No. 1 Tunnel and the China-Tajikistan Highway Phase II; the industrial park mainly includes China-Tajikistan Industrial Park, which develops and processes lead-zinc mines, China-Tajikistan New Silk Road Agricultural Textile Industrial Park, which is engaged in cotton planting and processing, and China-Tajikistan Agricultural Processing Park, which grows and processes food and vegetables.

China is the largest trading partner, largest creditor and second largest source of investment of Kyrgyzstan. From 2012 to 2016, bilateral trade volume between China and Kyrgyzstan rose to $\$ 5.376$ billion from $\$ 4.342$ billion. As of the end of 2016 , China's accumulated investment balance in Kyrgyzstan is 1.071 billion (about 1/4 of the accumulated balance of foreign investment in Kyrgyzstan). A total of 265 companies were registered, mainly investing in petrochemical, mineral resources mining, building materials and other fields [6]. The major cooperation projects between China and Tajikistan are mainly engineering contracting, such as Highway Planning and rail network planning of China Road and Bridge Group, "Datka-Keming" 500 by North-South Power Grid built by TB Group, reconstruction of substations and Bishkek thermal power plant renovation projects, reconstruction project of substation and Bishkek Thermal Power Plant, the Nalun River step station that State Grid Corporation of China developed, and China National Petroleum Group's medium-to-earth natural gas pipeline D line [6]. The main capacity cooperation projects include cement plants and fertilizer plants invested by Chinese companies in Kyrgyzstan.

China is Turkmenistan's largest trading partner. From 2012 to 2016, bilateral trade volume increased from 5,902 to 10,469 billion U.S. dollars (depending on gas prices). At the end of 2016, the stock of China's direct investment to Turkmenistan was 564.9 million dollars (according to Chinese statistics, the figure was $\$ 249$ million) [7]. China-Turkmenistan cooperation mainly focuses on large projects in the energy industry. For example, natural gas field development projects in South Yolotan areas, construction and operation project of Turkmenistan-China Gas Pipeline, Oil well repair and drilling projects of Sinopec Shengli Petroleum Administration; communication network transformation project of Huawei.

In September 2013, Chinese President Xi Jinping proposed the building of the "Silk Road Economic Belt" initiative to inject new impetus to the development of cooperation between China and Central Asian countries, and Central Asian countries responded enthusiastically and actively participate in. The docking of China and Central Asian countries have achieved good results, and has made great progress in the areas of mechanism, trade and investment, finance, production capacity, humanities, etc., and large projects have been implemented steadily. The practice has proved that the "Belt and Road" initiative has effectively tapped the development potential of Central Asian countries, promoted regional resource integration, and helped the economic transformation of Central Asian countries to achieve mutual benefit and win-win results.

The documents signed under the framework of "Belt and Road" initiative include "Sino-Kazakh Economic Cooperation and Long-term Development Plan (2020)", (September 2013), "Framework Agreement of Strengthening Cooperation of Industrial Capacity and Government's Investment" (August 2015), "Docking and Cooperation Plan of 'Silk Road Economic Belt' and 'Bright Road' New Economic Policy” (September 2016). Documents signed by China and Uzbekistan under the framework of "Belt and Road" 
initiative are "Protocol of Expanding Mutual Beneficial Economic and Trade Cooperation under the Framework of "Silk Road Economic Belt" on June 172015 and "Memorandum of Understanding on Commodity Trade Cooperation" in 2016 signed by commercial department of the two countries. In the "Belt and Road" International Cooperation Summit Forum of 2017, China's National Development and Reform Commission and the Ministry of Economic Affairs of Kyrgyzstan signed "Memorandum of Understanding of Jointly Promotion of Industrial Capacity and Key Investment Cooperation Projects".

Since the proposal of "Belt and Road" initiative, investment and trade cooperation between China and Central Asian countries has entered a new stage. China has become the largest trading partner and largest source of foreign direct investment in most of the Central Asian countries, which strongly supported the economic recovery of the Central Asian countries. Although the economic downturn and currency depreciation of Central Asian countries in 2014-2018 caused their bilateral trade volume with China declined, there has been no significant change in physical quantity. Trade volume of traditional main import and export commodities (oil, natural gas, cotton, minerals, agricultural products, etc.) has increased.

Fourthly, the effective expansion of energy cooperation between China and Central Asian countries has achieved mutual benefit and win-win situation. China has gained new sources of energy and guaranteed its diversification of energy imports, while Central Asian countries got access to Chinese investment, technology and a large and stable energy market. The energy cooperation between China and Central Asian countries is mainly concentrated in three aspects:

First of all, energy trade continues to increase. Since 2000, Central Asian countries have gradually become an important source of China's oil and gas resources (see Table 1). From the perspective of energy trade, China's import focus from Central Asian countries differs due to energy endowments. Natural gas accounts for a higher proportion of Central Asia's energy supply to China. In 2015, Central Asia's natural gas imports accounted for $87.36 \%$ of China's total imports, and oil imports accounted for less than $1.5 \%$ of China's total imports. Natural gas is mainly imported from Kazakhstan, Turkmenistan and Uzbekistan, and oil imports are mainly from Kazakhstan. The oil and gas supply adopts a supply mode of "mainly pipeline transportation, supplemented by road and rail transportation". In general, Central Asia is more dependent on Chinese oil exports than China's import dependence on Central Asia.

Judging from the differences in the diversity of cooperation content and the depth of cooperation, Kazakhstan is the country, which Chinese oil companies entered first, have the longest period and the widest range of cooperation development period, get the largest number of exploration and development rights and export most engineering technology services. Turkmenistan ranks second. With the construction of the China-Turkmenistan Gas Pipeline, China has also strengthened its cooperation with Turkmenistan in the field of natural gas technology services. China's oil and gas technology services in Uzbekistan have also evolved from the export of petroleum equipment spare parts and the provision of geophysical exploration, drilling and logging to the upgrading of engineering technologies such as old oil field recovery. The comprehensive, large-scale and high-level energy cooperation between China and Central Asian countries will not only change the energy pattern in Asia, but also have a profound impact on the world energy pattern. 
Table 1. Sources of China's Oil and Gas import in 2014

\begin{tabular}{|l|c|c|l|c|c|}
\hline \multicolumn{1}{|c|}{ Country } & $\begin{array}{c}\text { Oil Imports } \\
\text { (1 million } \\
\text { tons) }\end{array}$ & $\begin{array}{c}\text { Proportion } \\
(\%)\end{array}$ & \multicolumn{1}{|c|}{ Country } & $\begin{array}{c}\text { Natural } \\
\text { Gas Import } \\
\text { ( billion cubic } \\
\text { meters })\end{array}$ & $\begin{array}{c}\text { Proportion } \\
(\%)\end{array}$ \\
\hline Saudi Arabia & 49.67 & 16.11 & Turkmenistan & $\mathbf{2 5 . 4 9}$ & $\mathbf{4 3 . 7}$ \\
\hline Russia & 33.11 & 10.74 & Uzbekistan & $\mathbf{2 . 4 3}$ & $\mathbf{4 . 2}$ \\
\hline Oman & 29.74 & 9.64 & Kazakhstan & $\mathbf{0 . 4}$ & $\mathbf{0 . 7}$ \\
\hline Iraq & 28.54 & 9.27 & Qatar & 9.16 & 15.7 \\
\hline Iran & 27.46 & 8.9 & Indonesia & 3.47 & 6 \\
\hline $\begin{array}{l}\text { United Arab } \\
\text { Emirates }\end{array}$ & 11.65 & 3.78 & Malaysia & 4.07 & 7 \\
\hline Kuwait & 10.62 & 3.44 & Myanmar & 2.99 & 5.1 \\
\hline Kazakhstan & $\mathbf{5 . 6 9}$ & $\mathbf{1 . 8 5}$ & Yemen & 1.41 & 2.4 \\
\hline Africa & 65.04 & 22.06 & Australia & 5.18 & 8.9 \\
\hline $\begin{array}{l}\text { Central and South } \\
\text { America }\end{array}$ & 32.48 & 10.53 & Equatorial Guinea & 0.98 & 1.7 \\
\hline Total & 308.39 & 100 & total & 57.63 & 100 \\
\hline
\end{tabular}

Source: China Customs Statistical Yearbook (2015).

As of the beginning of 2016, China's total oil imports from Central Asian countries accounted for $1.85 \%$ of total oil imports, while natural gas imports accounted for $48 \%$ (see, Table 2.). The import of oil and gas resources in Central Asian countries effectively optimized China's overseas energy supply structure. At the same time, as China is such a large and stable export market, cooperation with China greatly promoted Central Asian countries' production of oil and gas resources, which led to rapid economic development.

Table 2. The Dependence of Oil and Gas Resources Exports from Central Asian Countries on China

\begin{tabular}{|c|c|c|c|c|c|c|c|c|c|}
\hline \multirow{2}{*}{$\begin{array}{l}\text { category } \\
\text { country }\end{array}$} & \multicolumn{3}{|c|}{$\begin{array}{c}\text { Central Asian oil and gas } \\
\text { exports } \\
\text { (1 billion U.S. dollars) }\end{array}$} & \multicolumn{3}{|c|}{$\begin{array}{l}\text { Central Asian countries' oil } \\
\text { and gas exports to China } \\
\text { (1 billion U.S. dollars) }\end{array}$} & \multicolumn{3}{|c|}{$\begin{array}{l}\text { Central Asian countries } \\
\text { account for China's oil and gas } \\
\text { exports }(\%)\end{array}$} \\
\hline & 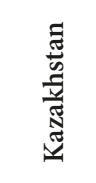 & 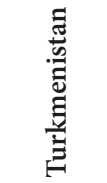 & 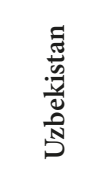 & 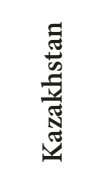 & 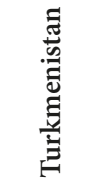 & 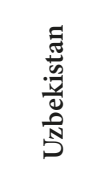 & 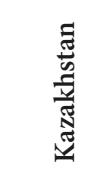 & 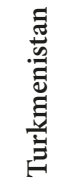 & 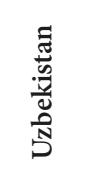 \\
\hline 2010 & 37.767 & 3.3973 & 0.5412 & 5.5442 & 1.2335 & 0.0394 & 14.7 & 36.3 & 7.3 \\
\hline 2011 & 57.591 & 9.5489 & 1.5431 & 9.6503 & 5.1225 & 0.0303 & 16.8 & 53.6 & 20 \\
\hline 2012 & 58.636 & 12.986 & 0.5623 & 9.1057 & 7.8744 & 0.1594 & 15.5 & 60.6 & 28.4 \\
\hline 2013 & 59.206 & 12.932 & 2.446 & 8.8855 & 8.6897 & 2.064 & 15.0 & 67.2 & 84.4 \\
\hline 2014 & 55.513 & 13.750 & 2.0835 & 5.0965 & 9.3231 & 1.758 & 9.2 & 67.8 & 84.4 \\
\hline
\end{tabular}

S ou r ce: United Nations Conference on Trade and Development (UNCTAD) database. 
Secondly, pipeline transportation cooperation has made breakthrough progress. The China-Kazakhstan oil pipeline is an important symbol of the construction of Eurasian oil and gas pipeline network of the $21^{\text {st }}$ century. In order to ensure the safety and development of oil and gas resources trade between China and Central Asian countries, in July 2004, China and Kazakhstan began to build China-Kazakhstan oil pipeline with a total length of more than 2,800 kilometers and an annual designed oil transportation capacity of 20 million tons. The first phase of the project was completed in 2006, and the second phase in 2009. This pipeline has become one of the most important transnational oil pipelines in China. By the end of 2015, China-Kazakhstan oil pipeline has delivered a total of 87.24 million tons of crude oil to China, with an annual oil output of more than 10 million tons. In August 2007, China, Turkmenistan, Kazakhstan and Uzbekistan began the joint construction of China- Central Asia gas pipeline. The pipeline is about 10,000 kilometers, which connects from west to east Turkmenistan, Uzbekistan, Tajikistan and Kyrgyzstan and China. Central Asia gas pipeline has 4 lines (A, B, C, and D). Line A, Line B and Line C were put into operation respectively in 2009, 2010 and 2014. From 2011 to the end of 2017, Line A, Line B and Line C imported a total of 195.9 billion cubic meters of natural gas. Natural gas imports in 2018 are expected to amount to nearly 50 billion cubic meters. In recent years, natural gas imported from Central Asian countries accounted for $52 \%$ of the total share of Chinass total imports (see Figure 1).

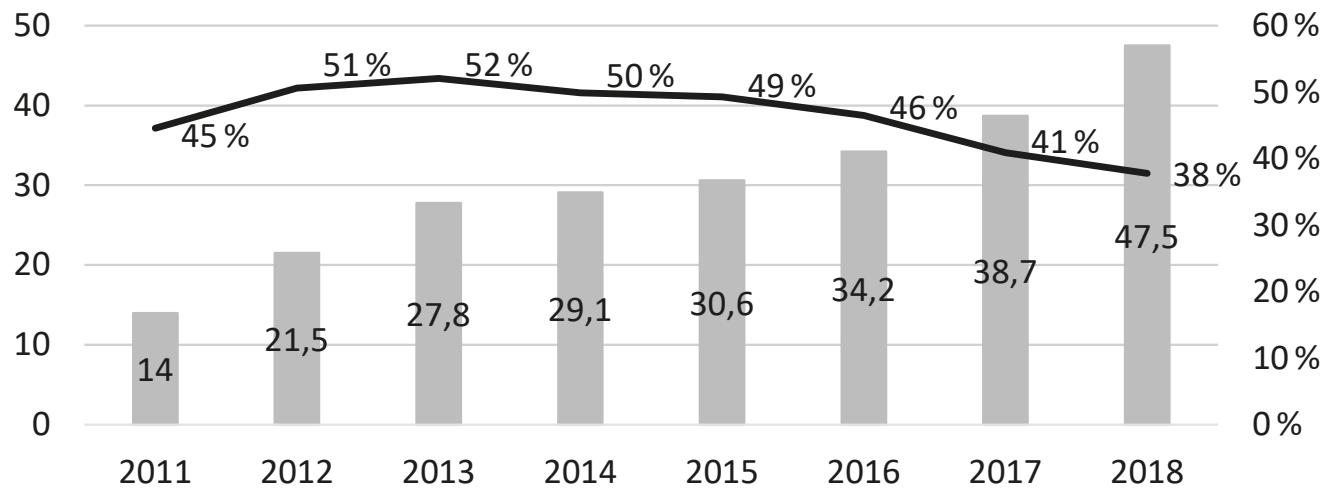

Gas imports from china-central Asia gas pipeline

The proportion of natural gas from central Asia Pipeline"

Figure 1. Volume and Proportion of Imported Natural Gas from "China-Central Asia Natural Gas

S ource: The author draws it according to the Customs data of the People's Republic of China.

Thirdly, cooperation of petroleum refining and petrochemical industries continues to promote and provide a powerful boost for the modernization of Central Asian countries' energy industry. Since the proposal of "Belt and Road" initiative in 2013, energy cooperation has become the pioneering industry and an important engine for the "Belt and Road" construction. Since the cooperation in the energy industry has saturated, the downward extension of industrial chain cooperation has become an important development direc- 
tion for energy industry cooperation between China and Central Asian countries. The refining and petrochemical projects carried out by China and Central Asian countries in recent years can be seen in Table 3 .

Table 3. China's Major Cooperation Projects in the Refining and Petrochemical Industries in Central Asia

\begin{tabular}{|l|l|l|l|l|}
\hline \multicolumn{1}{|c|}{$\begin{array}{c}\text { Chinese } \\
\text { company }\end{array}$} & \multicolumn{1}{|c|}{ project name } & Main partner & $\begin{array}{l}\text { cooperation } \\
\text { method }\end{array}$ & \multicolumn{1}{|c|}{ cooperative contents } \\
\hline Sinopec & $\begin{array}{l}\text { Petrochemical } \\
\text { complex plant } \\
\text { and infrastructure } \\
\text { project (2013) }\end{array}$ & $\begin{array}{l}\text { KPI } \\
\text { Corporation }\end{array}$ & contractor & $\begin{array}{l}\text { Construction of 500,000 tons / } \\
\text { year propane dehydrogenation unit } \\
\text { (PDH) and polypropylene unit (PP) }\end{array}$ \\
\hline Sinopec & $\begin{array}{l}\text { Kazakhstan } \\
\text { aromatics complex } \\
\text { project (2013) }\end{array}$ & contractor & $\begin{array}{l}\text { Annual production of 133,000 tons } \\
\text { of benzene and 496,000 tons of } \\
\text { p-xylene }\end{array}$ \\
\hline Sinopec & $\begin{array}{l}\text { Oil deep processing } \\
\text { combined device } \\
\text { of Atyrau Refinery } \\
\text { (2014) }\end{array}$ & $\begin{array}{l}\text { KPI } \\
\text { Corporation }\end{array}$ & contractor & $\begin{array}{l}\text { Construction of a 500,000 tons / } \\
\text { year propane dehydrogenation- } \\
\text { polypropylene unit }\end{array}$ \\
\hline $\begin{array}{l}\text { Jiai Technology } \\
\text { Company }\end{array}$ & $\begin{array}{l}\text { Tajikistan Dange } \\
\text { Refinery (2015) }\end{array}$ & & New & $\begin{array}{l}\text { Invested 900million US dollars, } \\
\text { refining capacity of 1.2 million tons }\end{array}$ \\
\hline
\end{tabular}

Source: Ministry of Commerce of China.

The fourth is to provide development assistance to Central Asian countries to help them ease urgent economic and humanitarian difficulties. Kyrgyzstan, Tajikistan and Uzbekistan are the main targets of China's official development assistance. China's official development assistance to Uzbekistan accounts for more than half of China's total aid to Central Asia. Kyrgyzstan and Tajikistan together account for about $40 \%$ of China's official development assistance to Central Asia. In a certain period of time in the future, China will become the largest official development aid country of Central Asia. China's official development assistance is mainly invested in the transportation and energy sectors. Unlike European countries, the United States, Japan and other donor countries, official development assistance provided by China only supports specific projects and does not impose political conditions. The purpose of China's aid is not to use aid to impose policy or other decision-making influence on aid recipients, but to hope to carry out some projects with significant impact.

The fifth is to carry out comprehensive cooperation with the Central Asian countries through the SCO. On June 15, 2001, SCO was set up, which is a new mechanism for regional cooperation and security in Eurasia, and has a special significance to promote the economic development of the Central Asian countries. It has also raised bilateral cooperation between China and Central Asian countries to a whole new level and has become an important platform for regional cooperation between China and Central Asian countries on a multilateral basis in the new century.

First of all, the principle of mutual trust and equality has been further clarified in politics, emphasizing good-neighborly friendship and mutual respect for sovereignty and territorial integrity, which can consolidate bilateral cooperation and make the interests of bilateral cooperation more solid. The various treaties and agreements signed within the 
framework of the SCO extended bilateral political cooperation between China and Central Asian countries.

Next, for the realization of economic trade, investment facilitation and deeper regional cooperation, deepen bilateral economic cooperation between China and Central Asian countries can play a catalytic role. Meetings of Heads of Government of the SCO repeatedly stressed the need to create conditions to facilitate members of the country's economic cooperation, the development of transport corridors and reduce tariff barriers and so on.

Again, mutual trust and cooperation in security, not only make the border between China and Central Asian countries a border of peace and friendship, but also maintain the stability of the entire region, which is a direct contribution to peace in Eurasia. Cooperation of China and Central Asian countries in combating the "Three Evil Forces" and cross-border crime has become an important part of the security cooperation of the SCO. Within the framework of the SCO, China and Central Asian countries signed agreements to expand substantive security cooperation. On the founding meeting of Shanghai Cooperation Organization in June 2001, heads of member states signed "Shanghai Convention on Fighting against Terrorism, Separatism and Extremism”. In June 2004, member states signed "Agreement of Shanghai Cooperation Organization Member States on Cooperation in Combating the Illicit Traffic in Narcotic Drugs, Psychotropic Substances and their Precursors". In July 2005, member states signed "Conception of Shanghai Cooperation Organization Member States on cooperation in combating terrorism, separatism and extremism" and other documents. The SCO also set up a Regional Anti-Terrorist Structure in Tashkent. The Attorney Generals' Meeting, the Supreme Court Presidents' meeting and the meeting of Ministers of Internal Affairs and Public Security, which are held within the framework of the Shanghai Cooperation Organization, are also related to security issues. In order to cooperate against terrorism, China and Central Asian countries also held a number of joint anti-terrorism military exercises. They have gradually institutionalized. Member states are also strengthening cooperation on security issues when holding important international events and multilateral projects.

Finally, China and Central Asian countries should support each other in international affairs. Both China and Central Asian countries advocate promoting mutual understanding and trust between countries and promoting regional peace and stability. The SCO has created more possibilities for cooperation between China and Central Asian countries on the international stage. On maintaining security and promoting the development of Central Asia, the position of China and Central Asian countries is similar in the broader international arena. There are many common interests. Central Asian leaders emphasized that the Shanghai Cooperation Organization is the most effective mechanism to safeguard regional peace and security, Central Asian countries attach importance to strengthening cooperation within the SCO framework with China, in order to maintain long-term stability in the region, making the area a model of cooperation.

The sixth is to balance the relationship between major powers in Central Asia. On the one hand, China respects the traditional influence and interests of Russia in Central Asia. The Chinese and Russian Ministries of Foreign Affairs have established a consultation mechanism on Central Asia, striving to seek common ground while reserving differences and avoiding the divergence of interests from being turned into open and uncontrollable contradictions and conflicts. The SCO has become an important platform for China 
and Russia to balance their interests and coordinate their positions. At the same time, China has never regarded Central Asia as its "sphere of influence" and fully respects the independent choice of Central Asian countries for diversified diplomacy. China also fully understands the interests of different actors, like the United States, the European Union, Japan, South Korea, India, and Turkey in Central Asia. China does not want confrontation or competition with those countries in Central Asia.

\section{The Future Trends of China's Strategy toward Central Asia}

Since the collapse of the Soviet Union in 1991, China and Central Asian countries have formed a strategic partnership of mutual respect, equality, mutual benefit and common development in the past 30 years, and carried out in-depth cooperation in the fields of politics, economy, security and humanities. Cooperation has created a good surrounding environment for China, safeguarded China's energy security, expanded new market space for China, and greatly protected the security of Central Asian countries and promoted their economic development, consolidated security and stability in the center of Eurasia.

In the future, China's strategy toward Central Asia will continue to be influenced by power changes of China, and Central Asian countries' attitude to China and interaction between China and other major powers in this region. The focus of China's Central Asia strategy for the next decade can be placed in the following areas:

The first is to further deepen security cooperation with Central Asian countries. Based on changes in the situation in Eurasia, the security cooperation between China and Central Asian countries must be continuously deepened and strengthened, and it cannot be relaxed and weakened. The SCO is the backbone of security in Central Asia. China must not only improve the level of security cooperation with Central Asian countries within the framework of SCO, but also increase the level of bilateral security cooperation with Central Asian countries and broaden the scope of cooperation. In bilateral security cooperation, China has been providing security cooperation assistance to Central Asian countries for many years. Based on the current security situation in Central Asia, China should increase its security assistance to Central Asian countries. On the hardware part, China should gradually help Central Asian countries to change the backwardness of equipment and facilities in Central Asia, and improve their self-defense ability, especially anti-terrorism ability. In terms of software, China should expand the training scale of national police and military personnel in Central Asia, and improve the ability of ChinaCentral Asian national security forces to coordinate their operations. Of course, on security cooperation between China and Central Asian countries, the feelings of Russia will be taken into account and its interests will never be challenged.

The second is to continuously optimize investment structure. Increasing infrastructure investment in Central Asian countries is a priority for China and Central Asia to build "Silk Road Economic Belt", and it is gradually changing the backwardness of infrastructure in Central Asian countries. However, according to the current economic structure and development level of Central Asian countries, the structure and scale of China's capital and technology investment should also be continuously optimized. The machinery manufacturing, processing industry and agriculture in Central Asia is still very backward. They badly need capital investment and technological innovation. When investing in in- 
frastructure, it is necessary to focus on people's livelihood which is closely related to national industry in Central Asia Thus, more people in Central Asian countries could enjoy benefits of the construction of "Silk Road Economic Belt". It will win more people's approval to build "Silk Road Economic Belt". Optimizing the investment structure must also consider the economic structure and situation of Central Asian countries from a macro perspective, make China's investment more balanced and scientific, avoid repetitive investment and construction as much as possible, and prevent overheating, overcapacity of certain areas caused by short-sighted concept.

The third is to exert the influence of soft power, strengthen and expand communication among people. Strengthening and expanding the communication among people is conducive to enhancing the political mutual trust between China and Central Asian countries, and deepening, expanding the awareness and understanding of the people of Central Asian countries on China, thus gradually eliminating misunderstandings about China and helping to weaken and eliminate breeding of the China Threat Theory". The first is to strengthen and expand people to people exchanges. On the basis of existing exchanges and cooperation on people to people exchange, China should continue to tap the potential of Confucius Institute, making it a platform of cultural exchanges for more people, and also expand cooperation scale and scope of Chinese universities and state colleges and universities in Central Asia, especially their cooperation in innovative ways. The second is to pay attention to the role of tourism media. China should expand tourism cooperation with Central Asian countries, open up new and convenient tourist routes, simplify tourist visa procedures, and open up more border holiday tours, let more media from both sides participate in the construction of "Silk Road Economic Belt". It is necessary to publicize and report on the results of cooperation between the two sides, not only to produce a series of special reports, but also to report on China's development and changes and the Chinese people's friendly feelings towards the people of Central Asian countries. The third is to give full play to the role of Chinese enterprises in the communication of hearts and minds of people. Chinese enterprises are distributed throughout Central Asia. Their words and deeds represent the image of China and directly affect the perception and attitude of Central Asian people toward China. Chinese enterprises should respect customs and habits of local people, abide by the local legal system, maintain corporate integrity, protect the ecological environment, do more social welfare undertakings, assume social responsibilities, and establish a good image of Chinese in the hearts of local people. In terms of investment, more attention should be paid to the investment and development of people's livelihood, so that the people of Central Asian countries can share the benefits brought by the construction of "Silk Road Economic Belt".

The fourth is to further strengthen constructive cooperation with other major powers in Central Asia. On the basis of continuing to respect Russia's traditional interests and realistic influences in Central Asia, China and Central Asian countries will jointly promote the multilateral economic and trade cooperation of SCO, promote the construction of a trans-Eurasian transportation corridor, and enable Russia to further develop its own transit transportation potential and obtain practical benefits. At the same time, China seeks to build constructive cooperation with the EU, Japan, South Korea, India, Turkey and even the United States in Central Asia to help Central Asian countries integrate more into the world economic system, promote the economic development and obtain wider security in Central Asia. 


\section{References}

1. BP Shijie nengyuan tongji nianjian 2016 [BP Energy Outlook: 2016 Chinese Edition]. Available at: https://www.bp.com/content/dam/bp-country/zh_cn/Publications/StatsReview2016/BP Stats Review_2016 中文版报告.pdf (accessed: 30.11.2018). (In Chinese)

2. Zhang Deguang: Shi Shanghezuzhi wei "Dongfang de beiyue" wu renhe genju [Zhang Deguang: "Groundless to View the SCO as the NATO in the East"]. Available at: http://china.rednet. cn/c/2006/06/02/906235.htm (accessed: 01.12.2018). (In Chinese)

3. Hu Jintao: Gongchuang Shanghaihezuozuzhi gengjia meihao de mingtian - zai Shanghaihezuozuzhi chengyuanguo yuanshou lishihui diliuci huiyi shang de jianghua [Hu Jintao: "Jointly Make A Better Future for the Shanghai Cooperation Organization" - the Speech at the Sixth Meeting of the SCO Council of the Heads of States]. $15^{\text {th }}$ June, 2016. Available at: http://politics.people.com.cn/ GB/1024/4477426.html (accessed: 01.12.2018). (In Chinese)

4. Zhonghuarenmingonghezuo Shangwubu. Duiwai touzi hezuo guobie (diqu) zhinan Hasakesitan (2017) [The Ministry of Commerce of PRC: the Guidelines of Foreign Investment Cooperation Country (Region) - Kazakhstan (2017)]. Available at: https://www.yidaililu.gov.cn/info/ilist.jsp?cat_ id $=10148$ (accessed: 01.12.2018). (In Chinese)

5. Zhonghuarenmingonghezuo Shangwubu. Duiwai touzi hezuo guobie (diqu) zhinan Wuzibiekesitan (2017) [The Ministry of Commerce of PRC: the Guidelines of Foreign Investment Cooperation Country (Region) - Uzbekistan (2017)]. Available at: https://www.yidaililu.gov.cn/info/ilist. jsp?cat_id=10148 (accessed: 01.12.2018). (In Chinese)

6. Zhonghuarenmingonghezuo Shangwubu. Duiwai touzi hezuo guobie (diqu) zhinan Jierjisisitan (2017) [The Ministry of Commerce of PRC: the Guideline of Foreign Investment Cooperation Country (Region) - Kyrgyzstan (2017)]. Available at: https://www.yidaililu.gov.cn/info/ilist.jsp?cat_ $\mathrm{id}=10148$ (accessed: 02.12.2018). (In Chinese)

7. Zhonghuarenmingonghezuo Shangwubu. Duiwai touzi hezuo guobie (diqu) zhinan Tukumansitan (2017) [The Ministry of Commerce of PRC: the Guidelines of Foreign Investment Cooperation Country (Region) - Turkmenistan (2017)]. Available at: https://www.yidaililu.gov.cn/info/ ilist.jsp?cat_id=10148 (accessed: 01.12.2018). (In Chinese)

Received: December 16, 2018

Accepted: January 15, 2019

Author's information:

Feng Yujun - PhD, Professor, Deputy Dean of Institute of International Studies, Director of Center for Russia and Central Asia Studies at Fudan University; yjfeng@fudan.edu.cn 